\title{
Budowa bariery jelitowej
}

\section{Structure of the intestinal barrier}

\author{
Dagmara Węgrzyn ${ }^{\bowtie}$, Karolina Adamek, Beata Łoniewska
}

Pomorski Uniwersytet Medyczny w Szczecinie, Klinika Patologii Noworodka, al. Powstańców Wlkp. 72, 70-111 Szczecin $\triangle$ dagpak@poczta.onet.pl

\begin{abstract}
The intestinal barrier consist of several layers. It is made of gut microbiota, a protective layer of mucus, intestinal epithelial cells, and the blood, lymphatic, immune and nervous systems. Mucus, which prevents the adhesion and penetration of pathogens to the intestinal wall, is also a habitat for intestinal microbiota - one of the key and most dynamic elements of the intestinal barrier. Microbiota mainly consist of anaerobic bacteria, and also aerobic bacteria, yeast and viruses. The intestinal ecosystem is constantly changing during human life, but tends to keep a balance, which is a guarantee of health. The single layer of the intestinal epithelium is a part of the physical barrier, which is mainly formed by enterocytes, which in addition to the absorption of
\end{abstract}

nutrients affect the development of immunity by mediating the release of cytokines and the expression of receptors involved in the immune response. Tight junctions are located at the apical ends of the lateral membranes of intestinal epithelial cells. They are the most important elements for maintaining intestinal permeability. Anchoring junctions and communicating junctions are also connections between epithelial cells. Under the layer of epithelial cells is the lamina propria, comprising intestinal lymphatic tissue, intestinal tract, and nervous system tissue. Continuous changes in the intestinal barrier influence the health and disease balance.

Keywords: intestinal barrier; microbiota; tight junction; gutassociated lymphoid tissue.

\begin{abstract}
ABSTRAKT
Bariera jelitowa jest zbudowana z kilku warstw. Tworzą ją mikroorganizmy jelitowe, ochronna warstwa śluzu, nabłonek jelitowy oraz komórki układu krwionośnego, chłonnego, immunologicznego i nerwowego. Warstwa śluzu, która zapobiega przyleganiu i wnikaniu patogenów w głąb ściany jelita, jest również siedliskiem mikroorganizmów jelitowych, które są jednym z kluczowych i najbardziej dynamicznych elementów bariery jelitowej. Mikrobiotę tworzą głównie bakterie beztlenowe, a także tlenowe, drożdże i wirusy. Eksosytem jelitowy podlega nieustannym zmianom w życiu człowieka, dąży jednak do zachowania równowagi, która jest gwarantem zdrowia. Elementem bariery fizycznej jest pojedyncza warstwa komórek nabłonkowych utworzona głównie przez enterocyty, które oprócz wchłaniania substancji
\end{abstract}

odżywczych wpływają na rozwój aktywności immunologicznej, pośrednicząc w uwalnianiu cytokin oraz ekspresji receptorów uczestniczących w odpowiedzi immunologicznej. Na szczytowo-bocznej powierzchni błony komórkowej zlokalizowane są ścisłe złącza. To one są najistotniejszym elementem regulującym przepuszczalność jelitową. Do połączeń między komórkami nabłonka należą także złącza mechaniczne oraz połączenia szczelinowe. Pod warstwą komórek nabłonkowych znajduje się blaszka właściwa, która zawiera jelitową tkankę limfatyczną, jelitowy układ nerwowy oraz tkankę łączną. Bariera jelitowa podlega ciągłym, dynamicznym zmianom, których wypadkowa warunkuje stan zdrowia lub choroby.

Słowa kluczowe: bariera jelitowa; mikrobiota; ścisłe złącza; jelitowa tkanka limfatyczna.

\section{WSTĘP}

Błona śluzowa jelit człowieka jest największą powierzchnią łączącą organizm ze środowiskiem zewnętrznym. Światło jelit stanowi swoistą niszę mikrobiologiczną. W stanie zdrowia zespół mikroorganizmów jelit tworzą bakterie, wirusy i grzyby. Bakterie komensalne powstrzymują na drodze konkurencji nadmierny rozwój pozostałych drobnoustrojów. W komórkach nabłonkowych jelita obywają się procesy absorpcji wody i elektrolitów oraz składników odżywczych z diety. Jednocześnie błona śluzowa zabezpiecza kontakt pomiędzy światłem jelita a komórkami układu odpornościowego, co jest niezbędne do wytworzenia odporności na bakterie komensalne i antygeny żywności. Równolegle połączenia ścisłe pomiędzy komórkami endothelium zabezpieczają przed wnikaniem do krwiobiegu patogenów, substancji toksycznych oraz innych czynników prozapalnych. Ten selektywny transport przez ściany jelita jest możliwy dzięki obecności bariery jelitowej $[1,2]$. Jak dowodzą badania naukowe, zmiany w jej przepuszczalności mogą być przyczyną zaburzeń głównie o podłożu metabolicznym oraz zapalnym [3].

\section{BUDOWA BARIERY JELITOWEJ}

Pierwszą linię obrony stanowi warstwa śluzu, która zapobiega przyleganiu i wnikaniu mikroorganizmów w głąb ściany jelita. Można w niej wyróżnić dwie części. Część zewnętrzna 
warstwy śluzowej jest bogata w peptydy przeciwbakteryjne produkowane przez komórki Panetha oraz immunoglobuliny A syntetyzowane przez komórki plazmatyczne. Jest to również siedlisko mikroorganizmów jelitowych będących jednym z kluczowych i najbardziej dynamicznych elementów bariery jelitowej. Wewnętrzna część warstwy śluzu jest grubsza i przylega bezpośrednio do komórek nabłonkowych. Odpowiada za ich nawodnienie, procesy regeneracji i chroni przed działaniem enzymów trawiennych. W jej skład wchodzi głównie glikokaliks wytwarzany przez komórki kubkowe. Jego zadanie dodatkowo polega na ograniczaniu przenikania antygenów do blaszki właściwej błony śluzowej. W badaniach na zwierzętach udowodniono, że utrata warstwy śluzu zwiększa przepuszczalność bariery jelitowej, co wiąże się z penetracją bakterii w głąb ściany przewodu pokarmowego i wyzwoleniem reakcji zapalnej [4].

Mikrobiotę tworzą głównie bakterie beztlenowe, a także tlenowe, drożdże i wirusy. Eksosytem jelitowy podlega nieustannym zmianom w życiu człowieka, dąży jednak do zachowania równowagi, która jest gwarantem zdrowia [5]. Należy zaznaczyć, że mikroflora jelitowa każdego człowieka ulega zmianom pod wpływem określonych czynników środowiskowych. Na skład ilościowy oraz jakościowy mikrobioty jelit ma wpływ przebieg ciąży i okresu okołoporodowego, rodzaj porodu, sposób karmienia małego dziecka (karmienie naturalne lub sztuczne), następnie dieta i styl życia w kolejnych latach, przyjmowane leki (głównie antybiotyki, steroidy, inhibitory pompy protonowej) oraz stany zapalne i wszelkie ingerencje chirurgiczne w obrębie przewodu pokarmowego. Czynniki te w sposób wyraźny wpływają na równowagę biocenozy mikrobiologicznej i mogą prowadzić do dysbiozy [6].

Flora jelitowa spełnia wiele funkcji w organizmie człowieka, m.in. metaboliczną, troficzną oraz immunologiczną, przy czym funkcje te uzupełniają się wzajemnie [7]. Metaboliczna aktywność bakterii jelitowych jest związana ze zdolnością flory do rozkładu niestrawionych resztek pokarmowych na drodze fermentacji, której produktem są m.in. krótkołańcuchowe kwasy tłuszczowe (short chain fatty acids) będące źródłem energetycznym dla kolonocytów. Wybrane rodzaje bakterii produkują witaminy, głównie K oraz z grupy B, a także zwiększają przyswajalność składników mineralnych. Poprzez produkcje hydrolazy mediują w procesie trawienia lipidów [8]. Poza tym bakterie jelitowe stymulują produkcję mucyn, które chronią nabłonek jelitowy przed inwazją patogenów i toksyn. Dodatkowo zaś działając na zasadach inhibicji kompetycyjnej o biotop oraz składniki odżywcze, bakterie komensalne jelit zapobiegają szkodliwej kolonizacji i namnażaniu bakterii chorobotwórczych. W proces ten równolegle zaangażowane są bakteriocyny będące produktem metabolizmu bakterii. Realizacja funkcji immunologicznej dotyczy mechanizmu sprawnej i szybkiej eliminacji szkodliwych antygenów na drodze molekularnej poprzez połączenie receptorów TLR (toll like receptors) oraz domen NOD (nucleotide oligomerisation domain) ze strukturami komórek bakterii, co ostatecznie wyzwala sekrecję mediatorów stanu zapalnego [9]. Jak dowodzą badania, zakłócenia homeostazy w obrębie mikrobioty wywołują zmiany w przepuszczalności bariery jelitowej, a implikacje kliniczne tych zmian obejmują zaburzenia metaboliczne, neurorozwojowe czy autoimmunologiczne. Jednocześnie spersonalizowane sterowanie składem mikroflory jelitowej poprzez suplementację probiotyków pomaga przywrócić równowagę ekosystemu jelitowego [10].

Kluczowym elementem fizycznej bariery jest pojedyncza warstwa komórek nabłonkowych, utworzona głównie przez enterocyty (80\%), które poza wchłanianiem substancji odżywczych wpływają na rozwój aktywności immunologicznej, pośrednicząc w uwalnianiu cytokin oraz ekspresji receptorów uczestniczących w odpowiedzi immunologicznej [11]. W warstwie nabłonkowej znajdują się także wspomniane już komórki kubkowe wydzielające śluz, komórki Panetha syntetyzujące defensyny, komórki enterochromatofilne uwalniające hormony i neuropeptydy oraz komórki M wychwytujące antygeny ze światła jelita [12]. Integralność nabłonka i jednocześnie selektywną przepuszczalność warunkującą transport bierny małych cząsteczek rozpuszczalnych w wodzie (drogą paracelularną) zapewniają odpowiednie połączenia między komórkami. Na szczytowo-bocznej powierzchni błony komórkowej zlokalizowane są ścisłe złącza (tight junctions - TJ) [13]. To one stanowią najistotniejszy element regulujący przepuszczalność jelitową. Połączenia ścisłe to kompleksy wielobiałkowe utworzone z 4 przezbłonowych protein: klaudyn, okludyn, białek adhezyjnych (junctional adhesion molecules - JAM) i triceluliny. Wewnątrzkomórkowe domeny tych białek wchodzą w interakcję z białkami cytozolu, tj. proteinami zonula occludens (ZO-1, Z0-2, ZO-3), które połączone są z włóknami aktynowymi cytoszkieletu enterocytów. Fosforylacja łańcuchów lekkich miozyny prowadzi do skurczu włókien aktynowych i rozluźnia strukturę TJ, co pozwala na transport substancji na drodze parakomórkowej [14]. W świetle danych z piśmiennictwa wiadomo, że komórki pozbawione ZO-1 zachowują zdolność tworzenia ścisłych złączy, które zapewniają prawidłową przepuszczalność [15], natomiast u pacjentów cierpiących z powodu zespołu jelita drażliwego i celiakii stwierdzono niską ekspresję białek ZO [16].

Obecnie wiadomo, że klaudyny są kluczowymi elementami złączy determinującymi integralność bariery jelitowej [13]. Zmiany budowy TJ polegające na zmniejszeniu ekspresji klaudyny-3, -4, -5 i -8 powodują osłabienie międzykomórkowego połączenia i sprzyjają rozwojowi nieswoistych chorób zapalnych jelit [17]. Podobnie obniżoną ekspresję klaudyny-3 i -4 zauważono w celiakii [18].

Jednocześnie w badaniach na zwierzętach typu knock-out genu okludyn udowodniono, że białka te są niezbędne do hamowania przepuszczalności międzykomórkowej makrocząsteczek [19]. W nieuszkodzonym nabłonku fosforylacja reszty serynowej, treoninowej i tyrozynowej okludyny prowadzi do utrzymania stabilności złącza [20]. Defosforylacja powoduje więc destabilizację struktury TJ, sprzyjając zwiększonej przepuszczalności. Słabą ekspresję okludyn stwierdzono w zespole jelita drażliwego oraz celiakii $[18,21]$.

Białka adhezyjne należą do podrodziny immunoglobulin, znajdują się na powierzchni komórek nabłonkowych, a także 
leukocytów oraz płytek krwi. W strukturze złączy TJ są reprezentowane przez białka: JAM-A, JAM-C, JAM-4, CAR oraz ESAM (endothelial cell-selective adhesion molecule). Wszystkie białka rodziny biorą udział w regulacji przepuszczalności jelitowej i procesów zapalnych [22]. W badaniach na zwierzętach wykazano, że brak genu kodującego białko JAM-A skutkował uszkodzeniem okrężnicy i rozwojem stanu zapalnego tej struktury [23].

Tricelulina uszczelnia przestrzeń między komórkami nabłonka, zapobiegając wnikaniu makrocząsteczek w głąb ściany jelita, jednocześnie pozwalając na transport jonów.

Do połączeń między komórkami nabłonka należą także złącza mechaniczne (adherent junctions) oraz połączenia szczelinowe (GAP junctions). Pierwsze utworzone są z desmosomów i kadheryn powiązanych z cytoszkieletem, co zapewnia ich dużą wytrzymałość mechaniczną. Połączenia szczelinowe składają się z 6 transbłonowych protein-koneksyn, które uczestniczą w dojrzewaniu i różnicowaniu komórek nabłonka, odgrywając istotną rolę w funkcjonowaniu bariery jelitowej [24].

Pod warstwą komórek nabłonkowych znajduje się blaszka właściwa, która zawiera jelitową tkankę limfatyczną ( gut-associated lymphoid tissue), jelitowy układ nerwowy oraz tkankę łączną. Układ limfatyczny jelita występuje w formie zorganizowanej tkanki limfatycznej będącej miejscem indukcji odpowiedzi immunologicznej. W strukturach tych za odpowiedź zapalną odpowiadają grudki chłonne, kępki Peyera oraz krezkowe węzły chłonne. Funkcję tę pełni poza tym rozproszona tkanka limfatyczna obejmująca głównie śródnabłonkowe limfocyty T CD8+, ale też komórki plazmatyczne, eozynofile, makrofagi, komórki tuczne czy komórki dendrytyczne [25]. Układ immunologiczny jelita odpowiada za transport antygenów z warstwy nabłonkowej do grudek chłonnych zlokalizowanych poniżej, gdzie komórki prezentujące antygen (antygen presenting cells) są prezentowane limfocytom, które ulegają przez to aktywacji $[26,27]$. Te zaś migrując do lokalnych węzłów chłonnych, aktywują odpowiedź immunologiczną przeciwko antygenom. W części rozproszonej jelitowej tkanki limfatycznej wytwarzane są komórki pamięci oraz komórki efektorowe syntetyzujące immunoglobuliny [26]. Komórki układu immunologicznego zawieszone są w tkance łącznej, która poza tym zawiera fibroblasty (produkujące kolagen i uczestniczące w proliferacji nabłonka), a także naczynia krwionośne i komórki jelitowego układu nerwowego odpowiadające za koordynację procesów trawienia, sekrecji wody i elektrolitów, regulację perystaltyki, przypływu naczyniowego oraz modulujące odpowiedź układu odpornościowego [22].

\section{WNIOSKI}

Współdziałanie elementów bariery jelitowej zapewnia odpowiednią, selektywną zdolność do absorbcji i sekrecji określonych substancji przy jednoczesnym ograniczeniu wnikania mikroorganizmów, toksyn i innych szkodliwych antygenów. Bariera jelitowa podlega ciągłym, dynamicznym zmianom, których wypadkowa warunkuje stan zdrowia lub choroby.
W badaniach klinicznych dowiedziono, że zakłócenie funkcji bariery jelitowej prowadzi do zwiększenia jej przepuszczalności i może być przyczyną oraz mediatorem przebiegu szeregu schorzeń przewlekłych. Udowodniono, że zaburzenia przepuszczalności bariery jelitowej odgrywają rolę w patogenezie nie tylko chorób przewodu pokarmowego, ale także układu nerwowego, immunologicznego czy rozrodczego [28, 29, 30, 31].

\section{PIŚMIENNICTWO}

1. Caricilli AM, Castoldi A, Câmara NO. Intestinal barrier: A gentlemen's agreement between microbiota and immunity. World J Gastrointest Pathophysiol 2014;5(1):18-32. doi: 10.4291/wjgp.v5.i1.18.

2. Rescigno M. Dendritic cells in oral tolerance in the gut. Cell Microbiol 2011;13(9):1303-8. doi: 10.1111/j.1462-5822.2011.01626.x.

3. Konig MF, Abusleme L, Reinholdt J, Palmer RJ, Teles RP, Sampson K, et al. Aggregatibacter actinomycetemcomitans-induced hypercitrullination links periodontal infection to autoimmunity in rheumatoid arthritis. Sci Transl Med 2016;8:369. doi: 10.1126/scitranslmed.aaj1921.

4. Kawashima H. Roles of the gel-forming MUC2 mucin and its O-glycosylation in the protection against colitis and colorectal cancer. Biol Pharm Bull 2012;35(10):1637-41.

5. Nowak A, Libudzisz Z. Ability of probiotic Lactobacillus casei DN 114001 to bind or/an metabolise hetereocyclic aromatic amines in vitro. Eur J Nutr 2009;48(7):419-27. doi: 10.1007/s00394-009-0030-1.

6. Cammarota G, Ianiro G, Bibbo S, Gasbarrini A. Gut microbiota modulation: probiotics, antibiotics or fecal microbiota transplantation? Intern Emerg Med 2014;9(4):365-73. doi: 10.1007/s11739-014-1069-4.

7. Krakowiak O, Nowak R. Mikroflora przewodu pokarmowego człowieka - znaczenie, rozwój, mody fikacje. Post Fitoter 2015;3:193-200.

8. Tappenden KA, Deutsch AS. The physiological relevance of the intestinal microbiota - contributions to human health. J Am Coll Nutr 2007;26(6):679-83.

9. Purchiaroni F, Tortora A, Gabrielli M, Bertucci F, Gigante G, Ianiro G, et al. The role of intestinal microbiota and the immune system. Eur Rev Med Pharmacol Sci 2013;17(3):323-33.

10. Wu M, Wu Y, Deng B, Li J, Cao H, Qu Y, et al. Isoliquiritigenin decreases the incidence of colitis-associated colorectal cancer by modulating the intestinal micro biota. Oncotarget 2016;7(51):85218-331. doi: 10.18632/ oncotarget.13347.

11. Van Der Flier L, Clevers H. Stem cells, self-renewal, and differentiation in the intestinal epithelium. Annu Rev Physiol 2009;71:241-60. doi: 10.1146/ annurev.physiol.010908.163145.

12. Pott J, Hornef M. Innate immune signalling at the intestinal epithelium in homeostasis and disease. EMBO Rep 2012;13(8):684-98. doi: 10.1038/ embor.2012.96.

13. Lee SH. Intestinal permeability regulation by tight junction: implication on inflammatory bowel diseases. Intest Res 2015;13(1):11-8. doi: 10.5217/ir.2015.13.1.11.

14. Turner JR, Rill BK, Carlson SL, Carnes D, Kerner R, Mrsny RJ, et al. Physiological regulation of epithelial tight junctions is associated with myosin light-chain phosphorylation. Am J Physiol 1997;273:1378-85.

15. Umeda K, Matsui T, Nakayama M, Furuse K, Sasaki H, Furuse M, et al. Establishment and characterization of cultured epithelial cells lacking expression of ZO-1. J Biol Chem 2004;279(43):44785-94. doi: 10.1074/ jbc.M406563200.

16. Drago S, El Asmar R, Di Pierro M, Grazia Clemente M, Tripathi A, Sapone A, et al. Gliadin, zonulin and gut permeability: Effects on celiac and nonceliac intestinal mucosa an intestinal cell lines. Scand J Gastroenterol 2006;41(4):408-19. doi: 10.1080/00365520500235334.

17. Zeissig S, Bürgel N, Günzel D, Richter J, Mankertz J, Wahnschaffe U, et al. Changes in expression and distribution of claudin 2, 5 and 8 lead to discontinuous tight junctions and barrier dysfunction in active Crohn's disease. Gut 2007;56(1):61-72. DOI: 10.1136/gut.2006.094375.

18. Sander GR, Cummins AG, Henshall T, Powell BC. Rapid disruption of intestinal barrier function by gliadin involves altered expression of apical 
junctional proteins. FEBS Lett 2005;579(21):4851-5. doi: 10.1016/j.febslet.2005.07.066.

19. Al-Sadi R, Khatib K, Guo S, Ye D, Youssef M, Ma T. Occludin regulates macromolecule flux across the intestinal epithelial tight junction barrier. Am J Physiol Gastrointest Liver Physiol 2011;300(6):1054-64. doi: 10.1152/ ajpgi.00055.2011.

20. Rao R. Occludin phosphorylation in regulation of epithelial tight junctions. Ann N Y Acad Sci 2009;1165:62-8. doi: 10.1111/j.1749-6632.2009.04054.x.

21. Martínez C, Lobo B, Pigrau M, Ramos L, González-Castro AM, Alonso C, et al. Diarrhoea-predominant irritable bowel syndrome: an organic disorder with structural abnormalities in the jejunal epithelial barrier. Gut 2013;62(8):1160-8. doi: 10.1136/gutjnl-2012-302093.

22. Salvo-Romero E, Alonso-Cotoner C, Pardo-Camacho C, Casado-Bedmar M, Vicario $\mathrm{M}$. The intestinal barrier function and its involvement in digestive disease. Rev Esp Enferm Dig 2015;107(11):686-96. doi: 10.17235/ reed.2015.3846/2015.

23. Laukoetter MG, Nava P, Lee WY, Severson EA, Capaldo CT, Babbin BA, et al. JAM-A regulates permeability and inflammation in the intestine in vivo. J Exp Med 2007;204(13):3067-76. doi: 10.1084/jem.20071416.

24. Kojima T, Murata M, Go M, Spray DC, Sawada N. Connexins induce and maintain tight junctions in epithelial cells. J Membr Biol 2007;217(1-3):13-9. doi: 10.1007/s00232-007-9021-4.
25. Gill N, Wlodarska M, Finlay B. Roadblocks in the gut: barriers to enteric infection. Cell Microbiol 2011;13(5):660-9. doi: 10.1111/j.1462-5822.2011.01578.x.

26. Jónsdóttir I. Maturation of mucosal immune responses and influence of maternal antibodies. J Comp Pathol 2007;137:20-6. doi: 10.1016/j. jcpa.2007.04.007.

27. Woodland DL, Randall TD. Anatomical features of anti-viral immunity in the respiratory tract. Semin Immunol 2004;16(3):163-70. doi: 10.1016/j. smim.2004.02.003.

28. Fasano A. Leaky gut and autoimmune diseases. Clin Rev Allergy Immunol 2012;42(1):71-8. doi: 10.1007/s12016-011-8291-x.

29. Prasad S, Mingrino R, Kaukinen K, Hayes KL, Powell RM, MacDonald TT, et al. Inflammatory processes have differential effects on claudins 2, 3 and 4 in colonic epithelial cells. Lab Invest 2005;85(9):1139-62. doi: 10.1038/ labinvest. 3700316 .

30. Nouri M, Bredberg A, Weström B, Lavasani S. Intestinal barrier dysfunction develops at the onset of experimental autoimmune encephalomyelitis, and can be induced by adoptive transfer of auto-reactive T cells. PLoS One 2014;9(9):106335. doi: 10.1371/journal.pone.0106335.

31. Zhang D, Zhang L, Yue F, Zheng Y, Russell R. Serum zonulin is elevated in women with polycystic ovary syndrome and correlates with insulin resistance and severity of anovulation. Eur J Endocrinol 2015;172(1):29-36. doi: 10.1530/EJE-14-0589. 